Human serum lipoproteins are strongly antigenic, and many repeatedly transfused patients develop iso-antibodies, which have led to the distinction of nine allotypes. The autoantibodies are of two principal types, neither related to the iso-antibody systems. Those described by Beaumont in hyperlipidaemia reacted with both high density (HDL) and low density (LDL) lipoproteins, and agglutination inhibition studies suggested that the reaction was with a phospholipid component present in human as well as animal serum lipoproteins. F. Mullinax and colleagues ${ }^{15}$ described a related antibody apparently directed at a choline hapten. Similar antibody activities have been found in experimentally induced mouse myeloma proteins. ${ }^{16} 17$

The antibodies associated with low lipid9 18 found in the rheumatoid syndrome mentioned above are different in that the antigenic sites lie on the protein part of the lipoprotein. Some react with the LDL only, others with both HDL and LDL, but all are strictly human-specific. As there is a large excess of antigen in the serum, antibodies may be fully combined, and activity can be detected only after splitting the complexes. This is usually the case with Beaumont's antibodies, while Noseda and colleagues were able to detect their antibodies directly by haemagglutination or gel precipitation. ${ }^{18}$ The reason why some types of immune complexes affect vessels and others the joints is not fully understood, but in the case of lipoprotein antibodies this may be influenced by the effect of these antibodies on the blood lipid levels. ${ }^{19}$

1 Lewis, L. A., and Page, I. H., American fournal of Medicine, 1965, 38, 286. 2 Beaumont, J-L., Annales de Biologie Clinique, 1969, 27, 611

3 Beaumont, J-L., European fournal of Clinical and Biological Research, 1970, 15, 1037 .

Lynch, P. J., and Winkelmann, R. K., Archives of Dermatology (Chicago), $1966,93,639$

5 Feiwel, M., British fournal of Dermatology, 1968, 80, 719.

- Kodama, H., Nakagawa, S., and Tanioku, K., Archives of Dermatology (Chicago), 1972, 105, 722.

7 Lewis, L. A., and Page, I. H., American fournal of Medicine, 1954, 17, 670.

8 Riesen, W., Noseda, G., and Butler, R., Vox Sanguinis, 1972, 22, 420.

- Noseda, G., Riesen, W., Schlumpf, E., and Morell, A., Schweizerische Medizinische Wochenschrift, 1972, 102, 969.

10 Windom, R. E., Sanford, J. P., and Ziff, M., Arthritis and Rheumatism, $1961,4,632$.

1 Waldmann, T. A., Johnson, J. S., and Talal, N., Fournal of Clinical Investigation, 1971, 50, 951.

12 Meltzer, M., and Franklin, E. C., American fournal of Medicine, 1966, 40, 828 .

13 Alpert, E., Isselbacher, K. J., and Schur, P. H., New England Fournal of Medicine, 1971, 285, 185 .

Goldman, J. A., Glueck, C. J., Abrams, N. R., Steiner, P., and Herman, J. H., Lancet, 1972, 2, 449 .

15 Mullinax, F., Himrod, B., and Berry, E. R., Clinical Research, 1970, 18,

16 Potter, M., New England Fournal of Medicine, 1971, 284, 831.

17 Leon, M. A., and Young, M., Biochemistry, 1971, 10, 1424.

18 Leon, M. A., and Young, M., Biochemistry, 1971, 10, 1424. Schweizerische Medizinische Wochenschrift, 1971, 101, 893.

1 Howard, A. N., Patelski, J., Bowyer, D. E., and Gresham, G. A., Atherosclerosis, 1971, 14, 17.

\section{General Knowledge of Cancer}

Education about cancer in Britain has been neglected for too long since the pioneer work of Malcolm Donaldson and the first long-term scientific study from Ralston Paterson's team in Manchester. ${ }^{1-3} \mathrm{~J}$. Wakefield has built up a group in Manchester which has provided much of the foundation research on which cancer education programmes throughout the world are based. 45 In Britain an important study of the attitudes of women in the Merseyside region was pub- lished by Mrs. P. Hobbs, ${ }^{6}$ confirming the Manchester work in a general way.

Now another important report has appeared giving an insight into the public attitudes prevailing in south-east Wales. ${ }^{7}$ This investigation has been supported by the Tenovus Cancer Information Centre in Cardiff. Eight hundred and one women and 203 men were interviewed, and these random samples were drawn from four areas, typifying the main different conditions of life in that part of the country. Many cross-tabulations of variables such as social class, age, education, and sex, as well as responses to the mass media, the experience of cancer, family size, and so on have been included in the report. It has been possible to make comparisons between the attitudes of men and women. There is a considerable difference between the sexes, men having a more positive, realistic, and optimistic approach than women; $61 \%$ of men against $47 \%$ of women thought cancer "sometimes curable."

Analyses by area showed that pessimism, fatalism, and insulation from current information affected all three social classes in two of the areas. This result needs to be taken account of in the design of future cancer education programmes, which must be adapted to the particular needs of the area to which they are directed. Two important groups of women-nurses and teachers-both gave a higher than average proportion of correct and informed answers, but even so it was disheartening to note that over $14 \%$ considered that cancer is never curable and $10 \%$ did not think that cigarette smoking could cause cancer. The educational influence of women in these groups is so strong and farreaching that it is vital to find ways of increasing their levels of knowledge.

A study of one particular area of education-that concerning cervical cytology-gave some interesting results. Only $9 \%$ of women in the whole sample could remember hearing or seeing a broadcast about cancer, and only $8 \%$ could recall reading an article about the subject. However, when specifically asked whether they had heard about the cervical test, it was found that $78 \%$ of the women had heard of it, and, of these, $30 \%$ had heard of it through medical sources - that is, clinics, hospitals, leaflets, and their family doctors; $40 \%$ had heard of it through mass media and $26 \%$ through relatives or friends. Only $4 \%$ said they had heard of it from general practitioners. The percentage of those who had heard of the test by word of mouth rose among the older people, while some $40 \%$ of those who had left school under $16 \mathrm{knew}$ about the test. This is valuable evidence for any educational programme. The survey disclosed much doubt and ignorance of symptoms. More effort is worth making to dispel this if we are to achieve the results we ought to do through early diagnosis and treatment. It is very encouraging that the Cancer Research Campaign has recently indicated that it will support research in the social sciences concerned with education of the public and the professions, and that this help will come through the medium of the British Cancer Council. This council is committed to research into education and communications in the cancer field.

The Tenovus report ends with a good summary of the importance of the work it has promoted: 'The 'public' is not a passive receiver of communications. It evolves its own patterns of opinions and knowledge about cancer, which, as our findings exemplify, are related to, but are certainly not determined by medical knowledge and opinions. It transmits and reinforces these patterns in many ways. Cancer 
education is a conscious and comparatively recent attempt to amend and re-shape the patterns so that they may conform more closely to current medical knowledge. There still remains a great deal that is not known about cancer. What is known is that if only people could be persuaded to act in accordance with the considerable knowledge that we do possess, much needless suffering would be avoided and the lives of thousands of people who now die prematurely would be saved."

\footnotetext{
1 Paterson, R., and Aitken-Swan, J., Lancet 1954, 2, 857

2 Aitken-Swan, J., and Paterson, R., British Medical fournal, 1955, 1,623 .

3 Paterson, R., and Aitken-Swan, J., Lancet, 1958, 2, 791.

4 Briggs, J. E., and Wakefield, J., Public Opinion on Cancer: A Survey of Knowledge and Attitudes Among Women in Lancaster 1966. Manchester, Report of Christie Hospital and Holt Radium Institute, 1967.

5 Davison, R. L., British Fournal of Preventive and Social Medicine, $1965,19,24$.

6 Hobbs, P., Public Opinions on Cancer: A Survey of Knowledge and Attitudes Among Women on Merseyside. Liverpool, Report of Merseyside Cancer Education Committee, 1968

7 Williams, E. M., Cruickshank, A., and Walker, W. M., Public Opinion on Cancer: A Report on the Findings of a Survey of Knowledge and Opinions Conducted in Four Areas of South-east Wales. Cardiff, Tenovus Information Centre, 1972.
}

\section{Pollution in Estuaries}

Since earliest times communities have been established along river banks, as the river provided a water supply and also a convenient means for the disposal of waste products. When industrial plants were being established which produced considerable quantities of trade effluents, it seemed reasonable to site them close to a tidal estuary on the assumption that the effluents would be rapidly dispersed to the open sea. This is now known not to happen, and most of our estuaries have a build up of pollution which falls with the ebb, only to return with the incoming tide. Moreover, pollutants such as mercury, lead, and cadmium settle in the estuarial mud and become a "deposit bank" which destroys marine and plant life. Concentration of organic mercury in marine organisms has led to outbreaks of mercury poisoning in Japan.

The pollutants discharged into estuaries originate from two main sources-industrial waste and sewage. The former may be toxic, while heavy discharges of sewage will contain pathogenic micro-organisms. The contamination is apt to destroy the amenities of the waterfront, and the toxic substances may completely destroy the marine life and damage birds and fish. There are two attitudes to pollution of this kind. The emotional reaction is to demand that the contamination should be stopped whatever the economic consequences. The opposing view is to play down the harm being caused, and to point out that the estuary serves mainly as a water highway and is beneficial to industry as easy discharge of effluent reduces costs. The conclusion of the recently published report of the Royal Commission on Environmental Pollution ${ }^{1}$ lies between these two views. It states, "However desirable it would be to remove contamination from estuaries, there is a practical limit to the burden which should be placed on the community to achieve this aim." The report also emphasizes that even if its recommendations for immediate improvements are put in motion it may take some time, even years, before the damage caused by past pollution will be overcome.

So far as infection is concerned, it is only occasionally that immersion in estuarial water is implicated as the source of salmonella infection, and from time to time cases of Weil's disease have been reported in persons falling into polluted docks. While sewage pollution of bathing beaches is aesthetically offensive, it has been held not to constitute a serious risk of infection. ${ }^{2} 3$ However, some recent research carried out at the American University School of Medicine, Beirut, would appear to cast some doubt on this finding. N. H. Nabbut and F. Kurayiyyah ${ }^{4}$ tested the viability of Salmonella typhi in sea water under various conditions. They consider that bathing in sewage-polluted sea water carries with it a risk to health in spite of the sea's dilution of pathogens and rapid self-purification. They state that this purifying process is incapable of coping with massive pollution problems and should not be relied on as the sole protection offered to bathers. Though "holiday typhoid" is featured prominently in a recent Health Department publication on typhoid and paratyphoid fevers, ${ }^{5}$ it has assumed that these infections are food-borne, and sea bathing is not mentioned as a source of infection.

In the past estuaries were important to maritime trade and industry. Today, with their increasing use for sports such as yachting, water-skiing, and other aquatic activities, the health dangers from pollution should be reassessed.

1 Royal Commission on Environmental Pollution, Third Report, Pollution in Some British Estuaries and Coastal Waters, Cmnd. 5054 London, H.M.S.O., 1972

2 Medical Research Council, Sewage Contamination of Bathing Beaches in England and Wales. Memorandum No. 37. London, H.M.S.O.,

3 Committee on Bathing Beach Contamination of the Public Health Laboratory Service, fournal of Hygiene, 1959, 57, 435.

4 Nabbut, N. H., and Kurayiyyah, F., fournal of Hygiene, 1972, 70, 223

5 Central Health Services Council, Typhoid and Paratyphoid Fevers, Executive Council Letter No. 118/72. London, Department of Health and Social Security, 1972.

\section{Coventry Meeting}

In the last few years the scope of the Annual Clinical Meetings of the B.M.A. has been extended by holding them jointly with various associations and societies. In 1969 the first clinical meeting was held overseas, in Malta, G.C., and last year the principles of a joint meeting and an overseas location were combined at the Annual Clinical Meeting in Cyprus. Next year will see two further innovations: the participation of a European association-the Danish Medical Association-and also, on the final day of the meeting, of the Junior Members Forum.

Besides the usual full programme (Supplement, p. 49) to bring doctors up to date with recent developments in such topics as immunotherapy of cancer, coronary insufficiency, and treatment of duodenal ulcer, the forthcoming British and Danish entry into the Common Market will be recognized by two symposia on undergraduate and further medical education in the E.E.C. A full social programme has been arranged and visitors can be assured of a warm welcome which the Midlands traditionally extend to those not fortunate enough to live in the heart of England.

The opportunity of attending refresher symposia in which world authorities will participate, of meeting colleagues from a country with many traditional links with Britain, and of visiting the Shakespeare country is one which many doctors will rightly not want to miss. They are urged to make their bookings early. 